\title{
Article \\ Chemical Properties and Bacterial Community Reaction to Acidified Cattle Slurry Fertilization in Soil from Maize Cultivation
}

\author{
Paweł Stanisław Wierzchowski ${ }^{1, *}{ }^{\mathbb{D}}$, Jakub Dobrzyński ${ }^{1}{ }^{(0}$, Kamila Mazur $^{1}{ }^{1}$, Marek Kierończyk ${ }^{1}{ }^{1}$, \\ Witold Jan Wardal ${ }^{1}$, Tomasz Sakowski ${ }^{2}$ and Jerzy Barszczewski ${ }^{1}$ \\ 1 Institute of Technology and Life Sciences, Falenty, Al Hrabska 3, 05-090 Raszyn, Poland; \\ j.dobrzynski@itp.edu.pl (J.D.); k.mazur@itp.edu.pl (K.M.); m.kieronczyk@itp.edu.pl (M.K.); \\ w.wardal@itp.edu.pl (W.J.W.); j.barszczewski@itp.edu.pl (J.B.) \\ 2 Institute of Genetics and Animal Biotechnology—Polish Academy of Sciences, Magdalenka, Posteppu 36A, \\ 05-552 Jastrzębiec, Poland; t.sakowski@ighz.pl \\ * Correspondence: s.wierzchowski@itp.edu.pl
}

Citation: Wierzchowski, P.S.; Dobrzyński, J.; Mazur, K.; Kierończyk, M.; Wardal, W.J.; Sakowski, T.; Barszczewski, J. Chemical Properties and Bacterial Community Reaction to Acidified Cattle Slurry Fertilization in Soil from Maize Cultivation. Agronomy 2021, 11, 601. https:// doi.org/10.3390/agronomy11030601

Academic Editors: Anna Gałązka, Agnieszka Wolińska and Vanessa Alvarez Lopez

Received: 10 February 2021

Accepted: 17 March 2021

Published: 22 March 2021

Publisher's Note: MDPI stays neutral with regard to jurisdictional claims in published maps and institutional affiliations.

Copyright: (c) 2021 by the authors. Licensee MDPI, Basel, Switzerland. This article is an open access article distributed under the terms and conditions of the Creative Commons Attribution (CC BY) license (https:// creativecommons.org/licenses/by/ $4.0 /)$.

\begin{abstract}
Acidified slurry is a novel organic fertilizer that limits gaseous ammonia emissions and reduces nitrogen losses. Our research aimed to determine the effects of short-term fertilization with acidified slurry on the chemical properties and bacterial community of soil used for maize cultivation. In the months after spreading, raw slurry fertilization had a significant impact on the increase in values of $\mathrm{N}-\mathrm{NO}_{3}$. In contrast, soil fertilized with acidified slurry had lower $\mathrm{N}-\mathrm{NO}_{3}$ values when compared to raw slurry fertilization treatments. Bacterial sequencing using Illumina MiSeq showed no differences in the genetic diversity of bacterial communities. In all tested soil samples, dominants at the phylum level were Actinobacteria, Proteobacteria, and Acidobacteria, while dominants at the class level were Actinobacteria, Alphaproteobacteria, Thermoleophilia, Gammaproteobacteria, and Acidimicrobiia. The values of biodiversity indices (Shannon index, Simpson index) in tested samples were similar. Our results suggest that short-term fertilization with acidified slurry does not adversely affect the biodiversity and structure of the bacterial communities and has a slight impact on soil chemical properties.
\end{abstract}

Keywords: acidified slurry; bacterial community; soil health; next-generation sequencing

\section{Introduction}

The ongoing process of agricultural intensification has an increasing impact on changes taking place in the natural environment [1]. One solution to this problem is the introduction of new fertilizer management systems which, in addition to minimizing harmful effects on the environment, also increase agricultural efficiency $[2,3]$.

Organic fertilizers are responsible for nearly $2 \%$ of the world's greenhouse gas emissions [4]. Ammonia $\left(\mathrm{NH}_{3}\right)$ emission is one of the more important problems associated with organic fertilizer management. Air pollution by ammonia causes a possible risk to human and animal health [5]. $\mathrm{NH}_{3}$ evaporation from liquid slurry represents more than $70 \%$ of the total emissions of this gas from agricultural sources [6]. Liquid animal slurry used as a fertilizer, in the first $24 \mathrm{~h}$ after application, loses up to $50 \%$ of its $\mathrm{NH}_{3}$ content in the form of gaseous emissions, which also contributes to a decrease in fertilization value. Volatilization of ammonia derived from fertilizers depends on the specific soil, and atmospheric conditions, such as high soil alkalinity, high moisture, and low soil buffering capacity [7]. The use of slurry acidification techniques (SAT) is one of the proposed solutions to reduce nitrogen losses and ammonia emissions [8-10]. The main aim of this procedure is to lower the slurry's pH to a value below 6.4 so that the $\mathrm{NH}_{3}-\mathrm{NH}_{4}$ equilibrium shifts towards the ionized form. SAT turn harmful and gaseous ammonia into aqueous ammonium that 
remains in the soil, while also contributing to the reduction in methane $\left(\mathrm{CH}_{4}\right)$ and nitrous oxide $\left(\mathrm{N}_{2} \mathrm{O}\right)$ emissions [11-13].

Maize (Zea mays L.), being one of the most cultivated cereals around the world, makes up an acreage of up to 196 million hectares, and in Europe approximately $11 \%$ of all crops are maize fields $[14,15]$. It is not only a food crop but also an industrial crop, with only $12-13 \%$ of its production used for direct human consumption. In Poland, maize acreage has increased since 2007 by over $146 \%$ and now makes up $8 \%$ of the total crop acreage in the European Union [16]. Maize, being an important and widely cultivated crop, is also one of the biggest recipients of organic and mineral fertilizers. Therefore, it is important to balance its sustainability and economic factors, while limiting negative environmental impact.

Microorganisms living in soil are abundant and highly diverse, and they are also sensitive to changes in environmental conditions [17]. Soil microorganisms take part in the soil's metabolism, thus playing a key role in maintaining its fertility and determining the long-term sustainable productivity of agricultural lands $[18,19]$. Because of their crucial importance in maintaining soil functions, there has been considerable effort invested in understanding the bacterial community response to disturbance or environmental change $[20,21]$. Studies across several types of soil demonstrated changes in microbial abundance depending on changes in the soil environment [22]. Proteobacteria, Firmicutes, Actinobacteria, and Bacteroidetes are often found to increase their overall share in bacterial communities due to $\mathrm{N}$ fertilization, while the relative abundance of Acidobacteria and Chloroflexi decrease [23,24].

So far, little attention has been given to the impact of acidified slurry on chemical properties, bacterial abundances, and biodiversity in soil [25]. Moreover, there is no research on bacterial community reactions to acidified slurry fertilization using highthroughput sequencing.

For these reasons, our study aimed to evaluate the possible consequences of acidified slurry fertilization on maize cultivation. We attempted to answer the following questions: does the use of acidified cattle slurry decrease the soil's $\mathrm{pH}$, and will any potential changes in the soil's $\mathrm{pH}$ have a consequence for the soil bacterial community?

\section{Materials and Methods}

\subsection{Study Site and Weather Conditions}

The field experiment that involved maize cultivation (Zea mays) was carried out between the 2017 and 2018 cropping seasons in Falenty, Mazovia, Poland $\left(52^{\circ} 08^{\prime} 37.4^{\prime \prime} \mathrm{N}\right.$ $20^{\circ} 55^{\prime} 42.1^{\prime \prime}$ E). According to World Reference Base [26] soil classification, the soil belonged to Chernozems, had a sandy loam texture, and the following chemical properties before fertilization (measured in 0-20 cm soil layers, March 2017): $\mathrm{pH} 6.4, \mathrm{~N}-\mathrm{NO}_{3} 7.74 \mathrm{mg} \mathrm{kg}^{-1}$, $\mathrm{N}-\mathrm{NH}_{4} 4.0 \mathrm{mg} \mathrm{kg}^{-1}$.

The experiment was set up as a completely randomized plot design with four replicates. Each plot had an area of $15 \mathrm{~m}^{2}$ with a buffer zone of $1.5 \mathrm{~m}$. Maize was harvested in September in both experimental years (2017 and 2018).

Meteorological data were gathered from the Warsaw-Okęcie weather station (EPWA 12375) located approximately $4 \mathrm{~km}$ away from the field experiment. The average annual air temperature in the experimental years was $10.9^{\circ} \mathrm{C}$ and the annual rainfall was $433.4 \mathrm{~mm}$ (Figure 1).

\subsection{Cattle Slurry Properties and Application}

Modified cattle slurry was obtained via slurry acidification technique according to Pedersen et al. [27]. The chemical properties of raw and acidified slurry are presented in Table 1.

In April 2017 and 2018, plots were fertilized with slurry and acidified slurry. The following fertilization treatments were applied: control (no fertilization); $84 \mathrm{~N} \mathrm{~kg} \cdot \mathrm{ha}^{-1}$ raw slurry (RS84); $84 \mathrm{~N} \mathrm{~kg} \cdot \mathrm{ha}^{-1}$ acidified slurry (AS84); $105 \mathrm{~N} \mathrm{~kg} \cdot \mathrm{ha}^{-1}$ raw slurry (RS105); and $105 \mathrm{~N} \mathrm{~kg} \cdot \mathrm{ha}^{-1}$ acidified slurry (AS105). The slurries were surface-spread using $10 \mathrm{~L}$ plastic 
watering cans in lines to imitate band spreading with a trailing hose. The fertilization rate of cattle slurries was calculated according to the slurry properties. Slurry $\mathrm{pH}$ values were measured directly in $50 \mathrm{~mL}$ of undiluted slurry that was previously stirred until homogenous. Slurry dry matter content was evaluated using a gravimetric method [28], total organic content (TOC) following ISO 10694 guidelines [29], total nitrogen (TN) using the Kjeldahl method [28], and $\mathrm{NH}^{4+}$ content using molecular absorption spectrophotometry [30].

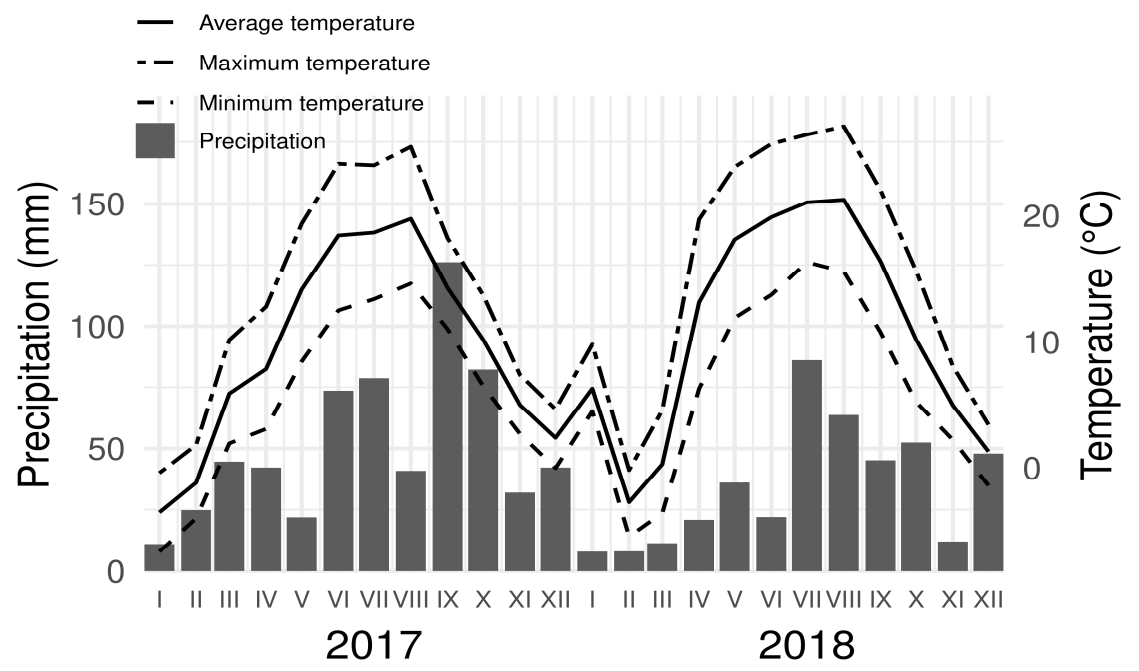

Figure 1. Average monthly air temperatures and precipitation during research years (2017-2018).

Table 1. Chemical properties of raw slurry and acidified slurry.

\begin{tabular}{|c|c|c|c|c|c|}
\hline Treatments & $\mathrm{pH}$ & Dry Matter Content (\%) & $\mathrm{TN}\left(\mathrm{kg} / \mathrm{m}^{3}\right)$ & $\mathrm{N}-\mathrm{NH}_{4}\left(\mathrm{~kg} / \mathrm{m}^{3}\right)$ & TOC in Dry Matter (\%) \\
\hline \multicolumn{6}{|c|}{2017} \\
\hline Raw slurry & 6.3 & 6.8 & 4.0 & 2.2 & 40 \\
\hline Acidified slurry & 5.4 & 6.6 & 3.8 & 1.9 & 38 \\
\hline \multicolumn{6}{|c|}{2018} \\
\hline Raw slurry & 6.7 & 7.4 & 4.1 & 1.8 & 41 \\
\hline Acidified slurry & 5.6 & 7.7 & 4.2 & 2.0 & 32 \\
\hline
\end{tabular}

\subsection{Soil Sampling and Chemical Analysis}

Soil samples for chemical analysis were taken from a depth of 0-20 cm in May (I) and August (II) in 2017 and in 2018. Samples for bacterial sequencing were collected in August 2018. Samples for sequencing were collected with a soil sampler probe from three random points from each treatment plot and mixed to form a composite sample. Soil samples for chemical analysis were taken from three random points from each of the four replicated treatment plots and then mixed to form a composite sample. Samples for chemical analysis were air-dried, ground, and passed through a $2 \mathrm{~mm}$ sieve. Samples for DNA extraction were stored at $-80^{\circ} \mathrm{C}$.

Soil $\mathrm{pH}$ values were measured potentiometrically in $1 \mathrm{M} \mathrm{KCl}$ (1:2.5; soil:solvent) using a Lab $860 \mathrm{pH}$ meter (SI Analytics $\mathrm{GmbH}$ ).

Soil $\mathrm{NH}^{4+}$ and $\mathrm{NO}^{3-}$ contents were determined by molecular absorption spectrophotometry in a Skalar segmented flow auto-analyzer (ScanPlus, Skalar, Breda, The Netherlands), using sulphanilamide and Berthelot methods [30].

\subsection{Sequencing}

Soil DNA isolation was carried out using a modified method based on the Genomic Mini AX Bacteria+ kit (A\&A Biotechnology). Additional mechanical lysis of the samples 
was done using a FastPrep-24 device with zirconium balls. After isolation, DNA was further purified using an Anti-Inhibitor kit (A\&A Biotechnology).

Sequencing of PCR amplicons of $16 \mathrm{~S}$ rRNA genes was carried out on the V3-V4 hypervariable regions. Specific 314F (5'-CCTACGGGNGGCWGCAG-3') and 785R (5'GACTACHVGGGTATCTAATCC-3' ${ }^{\prime}$ ) primer sequences were used to amplify the selected region and prepare the library. The PCR reaction was carried out using NEBNext ${ }^{\circledR}$ HighFidelity 2X PCR Master Mix. Sequencing took place using an Illumina MiSeq sequencer in paired-end (PE) technology $2 \times 250 \mathrm{nt}$ using Illumina v2 kit.

Sequencing data were deposited in NCBI Sequence Read Archive under BioProject accession PRJNA659882. The 16S rRNA gene sequence reads were processed with mothur [31]. Paired-end reads were merged and assembled using the make.contigs command. Pairs shorter than $400 \mathrm{bp}$, longer than $470 \mathrm{bp}$, or with an average Phred score quality below 25 were discarded. Chimeras were removed using the vsearch algorithm. The final reads were clustered into operational taxonomic units (OTUs) using the dist.seqs and cluster.split commands (opticlust algorithm) with a 0.03 distance cut off. A taxonomic identity was attributed to each OTU via the SILVA 132 rRNA database [32] using an 80\% homogeneity cut off. Reads were normalized by subsampling to the lowest number of obtained sequences in a sample. Rarefaction curves along with data used for figure generation is available in the supplementary materials (Figure S1, Tables S1 and S2).

\subsection{Statistics and Data Visualization}

Statistical analysis and visualization of sequencing data were done using R 3.5.3 statistical programming language [33] and the phyloseq package [34]. One-way ANOVA was used for the analysis of soil chemical parameters among treatments. Variance homogeneity was examined using the Levene test. The Wilk-Shapiro normality statistic was calculated to determine if residual values conformed to a normal distribution. Differences between treatments were tested using the Tukey-Kramer (HSD) test at $\alpha=0.05$ [35].

\section{Results}

\subsection{Chemical Properties}

The values of $\mathrm{pH}$ in the tested soils, regardless of treatment and year, did not differ statistically (Table 2). After slurry fertilization, values persisted at a similar level in all experimental variants.

Similar dependencies in the soil after the use of acidified slurry were noted by Edesi et al. [25], and the authors noted no significant changes in $\mathrm{pH}$ values regardless of the date, year, and variant of the experiment.

In the first year of research, $\mathrm{N}-\mathrm{NO}_{3}$ content in tested soil was significantly higher in all fertilized treatments in May and much lower in August. In 2018, similar results were observed. Significantly less $\mathrm{N}-\mathrm{NO}_{3}$ was recorded in AS84 and AS105 treatments, compared to the control plot and acidified treatments. The results noted are similar to those previously obtained by Edesi et al. [25] for pig slurry. However, in our study, favourable weather conditions in both years allowed a fast-paced conversion of $\mathrm{N}-\mathrm{NH}_{4}$ to $\mathrm{N}-\mathrm{NO}_{3}$ in the weeks after spreading. The lower values of $\mathrm{N}-\mathrm{NO}_{3}$ in acidified slurry treatments can be caused by a decrease in the intensity of nitrification processes after fertilization with acidified slurry $[8,36]$.

Regarding $\mathrm{N}-\mathrm{NH}_{4}$ content in the soil, there were no major differences in soils from different treatments in the first year of research. The values of this parameter in the first year of the study were very similar and ranged from 3.95 to $4.98 \mathrm{mg} \mathrm{kg}^{-1}$. In 2018, values of $\mathrm{N}_{-} \mathrm{NH}_{4}$ were significantly higher compared to 2017, and higher in soils fertilized with raw and acidified slurry when compared to the control plot. The lack of differences in the first year could have been caused by the rapid rate of the $\mathrm{N}-\mathrm{NH}_{4}$ to $\mathrm{N}-\mathrm{NO}_{3}$ conversion process carried out by soil microorganisms, and immediate nitrate uptake [23]. 
Table 2. Chemical properties of tested soil in May (I) and August (II) 2017 and $2018(n=4)$. Different letters behind the mean values indicate significant differences (Tukey-Kramer HSD test, $\alpha<0.05$ ).

\begin{tabular}{|c|c|c|c|c|c|c|c|c|c|c|c|c|}
\hline \multirow[b]{3}{*}{ Treatment } & \multicolumn{4}{|c|}{$\mathrm{NH}_{4}\left(\mathrm{mg} \mathrm{kg}^{-1}\right)$} & \multicolumn{4}{|c|}{$\mathrm{NO}_{3}\left(\mathrm{mg} \mathrm{kg}{ }^{-1}\right)$} & \multicolumn{4}{|c|}{$\mathrm{pH}$} \\
\hline & \multicolumn{2}{|c|}{2017} & \multicolumn{2}{|c|}{2018} & \multicolumn{2}{|c|}{2017} & \multicolumn{2}{|c|}{2018} & \multicolumn{2}{|c|}{2017} & \multicolumn{2}{|c|}{2018} \\
\hline & I & II & I & II & I & II & I & II & I & II & I & II \\
\hline RS84 & $4.56^{\mathrm{a}}$ & $3.99^{\mathrm{a}}$ & $6.16^{\mathrm{a}}$ & $5.74^{a}$ & $17.64^{\mathrm{a}}$ & $7.20^{a b}$ & $18.62^{\mathrm{a}}$ & $7.09^{a b}$ & $6.37^{a}$ & $6.33^{a}$ & $6.82^{a}$ & $6.39^{a}$ \\
\hline AS84 & $4.51^{\mathrm{a}}$ & $3.97^{\mathrm{a}}$ & $6.61^{\mathrm{a}}$ & $5.96^{\mathrm{a}}$ & $13.36^{\mathrm{ab}}$ & $6.79 \mathrm{ab}$ & $15.38^{a b}$ & $10.39^{a}$ & $6.57^{\mathrm{a}}$ & $6.53^{\mathrm{a}}$ & $6.83^{a}$ & $6.74^{\mathrm{a}}$ \\
\hline RS105 & $4.98^{\mathrm{a}}$ & $3.95^{\mathrm{a}}$ & $6.57^{\mathrm{a}}$ & $5.88^{a}$ & $16.62^{\mathrm{a}}$ & $7.75^{\mathrm{a}}$ & $20.06^{\mathrm{a}}$ & $9.22^{a b}$ & $6.44^{\mathrm{a}}$ & $6.74^{\mathrm{a}}$ & $6.61^{\mathrm{a}}$ & $6.62^{\mathrm{a}}$ \\
\hline AS105 & $4.47^{\mathrm{a}}$ & $4.06^{\mathrm{a}}$ & $6.81^{\mathrm{a}}$ & $6.07^{a}$ & $12.68^{\mathrm{ab}}$ & $6.38^{\mathrm{ab}}$ & $12.96^{b c}$ & $7.35^{\mathrm{ab}}$ & $6.66^{\mathrm{a}}$ & $6.82^{a}$ & $6.44^{\mathrm{a}}$ & $6.35^{\mathrm{a}}$ \\
\hline 0 & $4.07^{\mathrm{a}}$ & $4.01^{\mathrm{a}}$ & $3.89^{b}$ & $3.79^{b}$ & $8.77^{b}$ & $5.74^{b}$ & $8.84^{c}$ & $5.80^{\mathrm{b}}$ & $6.25^{a}$ & $6.67^{a}$ & $6.74^{a}$ & $6.52^{\mathrm{a}}$ \\
\hline $\operatorname{Pr}(>F)$ & ns & ns & $<0.001$ & $<0.001$ & $<0.001$ & 0.057 & $<0.001$ & 0.018 & $\mathrm{~ns}$ & $\mathrm{~ns}$ & ns & ns \\
\hline
\end{tabular}

\subsection{Bacterial Community Composition}

A total of 960,393 16S bacterial raw reads were obtained from five samples. After quality filtering a total of 733,630 reads were obtained (123590 unique), with an average of 146,726 reads per sample. A total of 36,595 unique OTUs were formed after binning with a $97 \%$ similarity rate.

Bacterial biodiversity indexes in tested soil samples were similar, as both the Shannon and Simpson values did not differ (Table 3).

Table 3. Biodiversity indexes, operational taxonomic unit (OTU) numbers, and total reads after processing.

\begin{tabular}{cccccc}
\hline Sample & Shannon Index & Simpson Index & OTUs & Reads & Coverage \\
\hline 0 & 7.42 & 0.002321 & 13,243 & 157,900 & $94.58 \%$ \\
\hline RS84 & 7.43 & 0.002406 & 13,669 & 161,045 & $94.33 \%$ \\
\hline RS105 & 7.28 & 0.002863 & 12,169 & 133,044 & $94.77 \%$ \\
\hline AS84 & 7.19 & 0.004599 & 12,549 & 138,232 & $94.65 \%$ \\
\hline AS105 & 7.18 & 0.004130 & 12,240 & 143,409 & $94.80 \%$ \\
\hline
\end{tabular}

* Read depth after normalization-133044.

The Shannon index ranged from 7.18 (AS105) to 7.43 (RS84), and the Simpson index from 0.002321 (0) to 0.004599 (AS84). Similar regularities were noted by Das et al. [37], who, after applying composted cattle manure and swine manure in submerged rice paddy, did not find significant differences in bacterial diversity indices compared to the control. In addition, Hartmann et al. [38], studying soil from crop rotations (winter wheat and grass clover), did not observe significant differences in bacterial richness and evenness in conventional manure fertilization in comparison with control plots.

One of the most important aspects of next generation sequencing (NGS) is the ability to identify key taxa carrying out important biochemical reactions in the soil. The analysis of the taxonomic composition of the microbiota derived from the tested soil showed that the dominants at the phylum level included Actinobacteria (37.32-41.80\%), Proteobacteria (24.50-25.61\%), and Acidobacteria (9.86-11.61\%) (Figure 2).

Dominants at the class level, among others, included Actinobacteria (13.97-21.08\%), Alphaproteobacteria (11.36-12.54\%), Thermoleophilia (9.79-12.80\%), Gammaproteobacteria (8.41-9.62\%), and Acidimicrobiia (6.40-7.83\%). In addition, some OTUs were assigned to groups of microorganisms that remained unclassified. The most numerous such group in the samples tested was Subgroup_6_or (6.10-7.22\%), which included non-culturable bacteria belonging to the phylum Acidobacteria (Figure 3). 


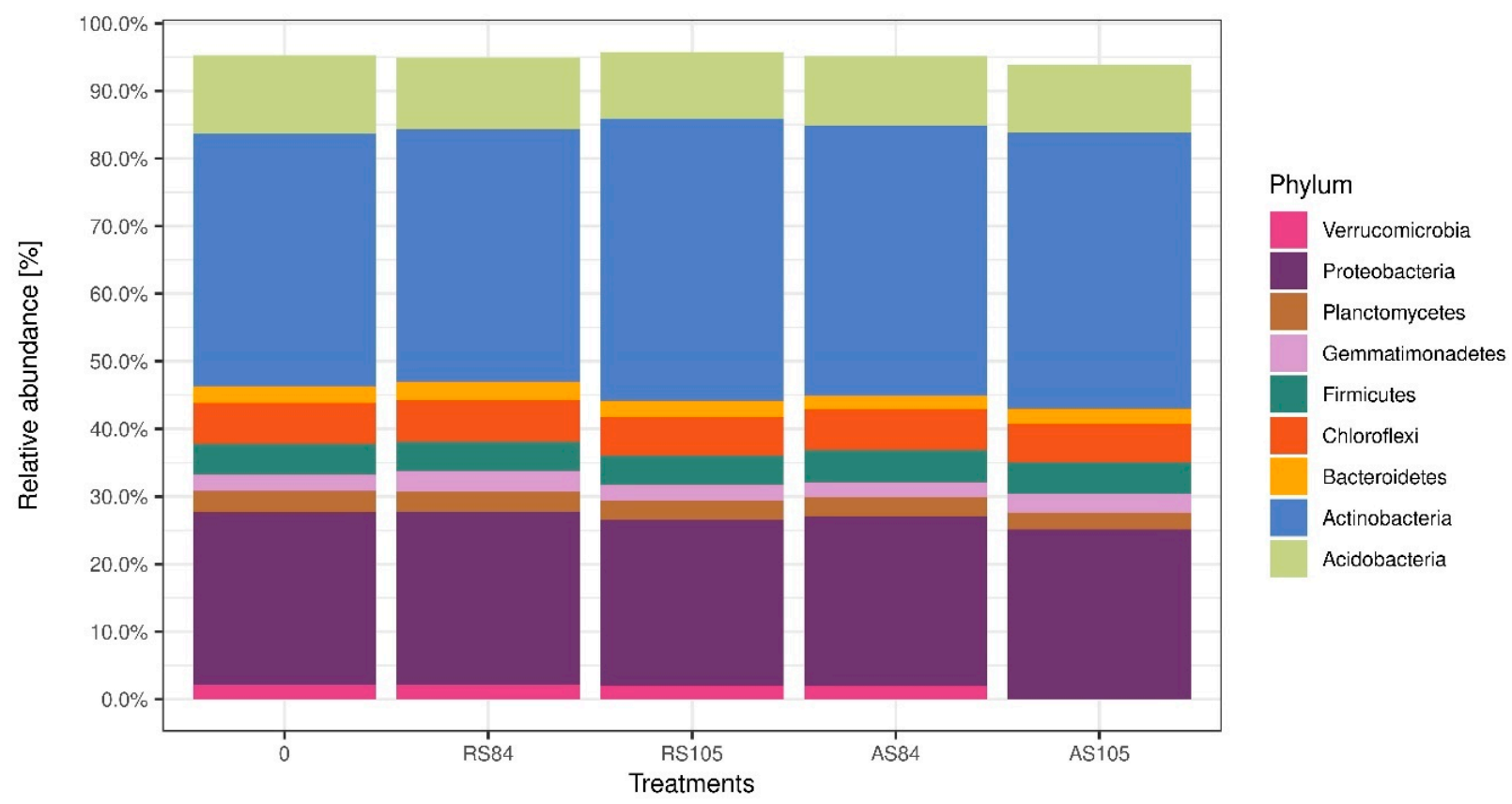

Figure 2. Bacterial abundances at the phylum level. 0— control treatment, no fertilization applied; AS84-84 N kg.ha ${ }^{-1}$, AS105-105 N kg.ha ${ }^{-1}$, RS84-84 N kg.ha ${ }^{-1}$, and RS105-105 N kg.ha ${ }^{-1}$. Only taxa above $\%$ abundancy are shown.

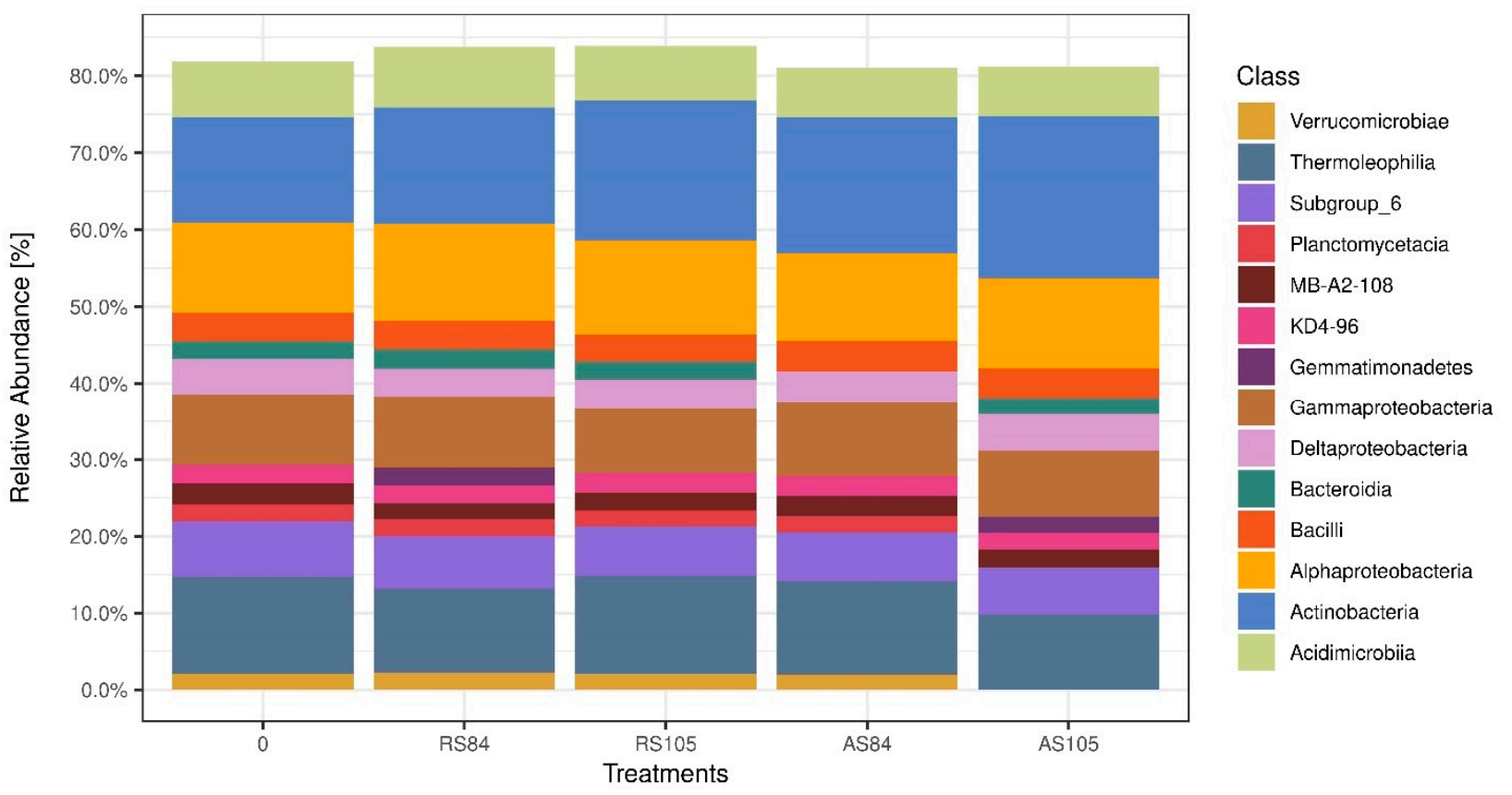

Figure 3. Bacterial abundances at the class level. 0—control treatment, no fertilization applied; AS84-84 N kg.ha ${ }^{-1}$, AS105-105 N kg.ha ${ }^{-1}$, RS84-84 N kg.ha ${ }^{-1}$, and RS105-105 N kg.ha ${ }^{-1}$. Only taxa above $\%$ abundancy are shown.

The results obtained on the percentage share of dominates at the phylum level are often reproduced in other papers. Based on terminal restriction fragment length polymorphism (T-RFLP), Hartmann and Widmer [39] stated that the dominants in agricultural soils include bacteria from the phyla Actinobacteria (35-39\%), Proteobacteria (26-33\%), and Acidobacteria (11-13\%), and less commonly, Firmicutes (3-6\%), Bacteroidetes (2-3\%), and Chloroflexi (1-2\%). In later years, many studies created thanks to next-generation sequencing confirmed this thesis [40]. Most of these studies examined the effects of longterm mineral and organic fertilization on soil microbiota [41-44]. Fertilization with manure, liquid manure, or slurry may stimulate the development of copiotrophic bacteria, such as 
those belonging to the phyla Actinobacteria, Proteobacteria, or Firmicutes. These bacteria multiply rapidly when large amounts of organic matter are introduced. However, larger amounts of carbon and nitrogen do not affect the development of oligotrophic bacteria, which include mainly Acidobacteria. This group of bacteria has a more economical life strategy than copiotrophic bacteria and occurs in soils poor in nutrients [45-47]. Therefore, the introduction of large amounts of organic matter into the soil can interfere with the natural O:K ratio and thus negatively affect biological soil homeostasis [48].

No changes in the structure of bacterial communities were noted due to the use of acidified and non-acidified slurry. Our results are supported by the study from Edesi et al. [25]. Despite using different methods, these authors noted no significant impact of pig slurry on the bacterial community using phospholipid fatty acid (PLFA) extraction [49]. Because of the short-term nature of the fertilization experiment, the bacterial community quickly returned to its initial state, and permanent changes in the bacterial community are usually observed only after long-term fertilization [50]. However, some publications suggest a significant effect of short-term fertilization on the soil microbiome [51,52]. The discrepancy between the possible effects of short-term fertilization on soil microbiota can be attributed to the wide range of applied agricultural treatments and practices [53,54].

No differences were noted between the applied fertilization doses. Several papers present similar results. Stark et al. [55], after applying fertilization for 91 days, found no change in the bacterial community compared to control treatment. Similar regularities were also found in the case of research conducted by Roberts et al. [56], who used nitrogen fertilization at 20 or $130 \mathrm{~kg} \mathrm{ha}^{-1}$ for 3 years.

\section{Conclusions}

Fertilization with acidified slurry did not cause a major shift in the chemical properties of the tested soil. However, it lowered the content of $\mathrm{NO}_{3}-\mathrm{N}$ one month after spreading with acidified slurry in both years, in comparison to control and raw slurry treatments. Moreover, our findings based on soil sequencing show that short-term fertilization with acidified slurry did not cause an immediate shift in bacterial community structure. According to data available in other studies about the effects of long-term fertilization, it can be only hypothesized that prolonged use of acidified slurry might cause significant changes in the abundances and presence of certain bacterial taxa. Our paper is one of the first to use NGS (DNA) taxonomic profiling in the study of acidified slurry and its influence on the soil. However, it did not answer questions regarding the RNA profile, and did not cover all of the soil's chemical properties.

There is a need for further research on this issue, but at this time, the use of acidified slurry as fertilizer seems to be an environmentally safe way of increasing maize yields while limiting ammonia and other potentially harmful gaseous emissions.

Supplementary Materials: The following are available online at https:/ / www.mdpi.com/2073-439 5/11/3/601/s1. Table S1: Figure 2 Data, Table S2: Figure 3 Data. Figure S1: Rarefaction curves.

Author Contributions: Conceptualization, J.D.; Data curation, P.S.W. and M.K.; Formal analysis, K.M.; Funding acquisition, K.M. and W.J.W.; Investigation, M.K. and W.J.W.; Methodology, P.S.W. and J.D.; Project administration, K.M., M.K., and W.J.W.; Resources, K.M. and W.J.W.; Software, P.S.W.; Supervision, T.S. and J.B.; Validation, M.K.; Visualization, P.S.W.; Writing-original draft, P.S.W. and J.D.; Writing - review and editing, P.S.W. and J.D. All authors have read and agreed to the published version of the manuscript.

Funding: Research done under the INTERREG Baltic Slurry Acidification project titled “Reducing nitrogen loss from livestock production by promoting the use of slurry acidification techniques in the Baltic Sea Region", under the contract with the Polish Ministry of Science and Higher Education number 3712/INTERREG BSR/2017/2 concerning the implementation of the internationally financed project number W27/INTERREG BSR/2017(01.03.2016-28.02.2019).

Institutional Review Board Statement: Not applicable.

Informed Consent Statement: Not applicable. 
Data Availability Statement: Sequencing data available under the following accession number: PRJNA659882 (https: / / www.ncbi.nlm.nih.gov/bioproject/PRJNA659882/ accessed on 19 March 2021).

Conflicts of Interest: The authors declare no conflict of interest.

\section{References}

1. Burzyńska, I. Monitoring of Selected Fertilizer Nutrients in Surface Waters and Soils of Agricultural Land in the River Valley in Central Poland. J. Water Land Dev. 2019, 43, 41-48. [CrossRef]

2. Sørensen, C.A.G.; Sommer, S.G.; Bochtis, D.; Rotz, A. Technologies and Logistics for Handling, Transport and Distribution of Animal Manures. In Animal Manure Recycling; John Wiley \& Sons, Ltd.: Hoboken, NJ, USA, 2013; pp. 211-236. ISBN 978-1-118-67667-7.

3. Kiełbasa, B.; Pietrzak, S.; Ulén, B.; Drangert, J.-O.; Tonderski, K. Sustainable Agriculture: The Study on Farmers' Perception and Practices Regarding Nutrient Management and Limiting Losses. J. Water Land Dev. 2018, 36, 67-75. [CrossRef]

4. Ten Hoeve, M.; Nyord, T.; Peters, G.M.; Hutchings, N.J.; Jensen, L.S.; Bruun, S. A Life Cycle Perspective of Slurry Acidification Strategies under Different Nitrogen Regulations. J. Clean. Prod. 2016, 127, 591-599. [CrossRef]

5. Ritz, C.W.; Fairchild, B.D.; Lacy, M.P. Implications of Ammonia Production and Emissions from Commercial Poultry Facilities: A Review. J. Appl. Poult. Res. 2004, 13, 684-692. [CrossRef]

6. Dalgaard, T.; Hansen, B.; Hasler, B.; Hertel, O.; Hutchings, N.J.; Jacobsen, B.H.; Jensen, L.S.; Kronvang, B.; Olesen, J.E.; Schjørring, J.K.; et al. Policies for Agricultural Nitrogen Management-Trends, Challenges and Prospects for Improved Efficiency in Denmark. Environ. Res. Lett. 2014, 9, 115002. [CrossRef]

7. Fenilli, T.A.B.; Reichardt, K.; Trivelin, P.C.O.; Favarin, J.L. Volatilization of Ammonia Derived from Fertilizer and Its Reabsorption by Coffee Plants. Commun. Soil Sci. Plant Anal. 2007, 38, 1741-1751. [CrossRef]

8. Fangueiro, D.; Ribeiro, H.; Coutinho, J.; Cardenas, L.; Trindade, H.; Cunha-Queda, C.; Vasconcelos, E.; Cabral, F. Nitrogen Mineralization and $\mathrm{CO}_{2}$ and $\mathrm{N}_{2} \mathrm{O}$ Emissions in a Sandy Soil Amended with Original or Acidified Pig Slurries or with the Relative Fractions. Biol. Fertil. Soils 2010, 46, 383-391. [CrossRef]

9. Rodrigues, J.; Alvarenga, P.; Silva, A.C.; Brito, L.; Tavares, J.; Fangueiro, D. Animal Slurry Sanitization through PH Adjustment: Process Optimization and Impact on Slurry Characteristics. Agronomy 2021, 11, 517. [CrossRef]

10. Wardal, W.; Kieronczyk, M.; Barwicki, J.; Borek, K.; Mazur, K.; Konieczna, A. Legal Conditions for the Use of Sulfuric Acid in Liquid Manure to Reduce Nitrogen Losses [Uwarunkowania Prawne Stosowania Dodatku Kwasu Siarkowego Do Gnojowicy w Celu Zmniejszenia Strat Azotu]. Przem. Chem. 2019, 98, 1179-1183. [CrossRef]

11. Berg, W.; Brunsch, R.; Pazsiczki, I. Greenhouse Gas Emissions from Covered Slurry Compared with Uncovered during Storage. Agric. Ecosyst. Environ. 2006, 112, 129-134. [CrossRef]

12. Fangueiro, D.; Hjorth, M.; Gioelli, F. Acidification of Animal Slurry-A Review. J. Environ. Manag. 2015, 149, 46-56. [CrossRef] [PubMed]

13. Ottosen, L.; Poulsen, H.; Nielsen, D.; Finster, K.; Nielsen, L.P.; Revsbech, N. Observations on Microbial Activity in Acidified Pig Slurry. Biosyst. Eng. 2009, 102, 291-297. [CrossRef]

14. Halli, H.M.; Angadi, S.; Kumar, A.; Govindasamy, P.; Madar, R.; El-Ansary, D.O.; Rashwan, M.A.; Abdelmohsen, S.A.M.; Abdelbacki, A.M.M.; Mahmoud, E.A.; et al. Influence of Planting and Irrigation Levels as Physical Methods on Maize Root Morphological Traits, Grain Yield and Water Productivity in Semi-Arid Region. Agronomy 2021, 11, 294. [CrossRef]

15. FAOSTAT. Available online: http://www.fao.org/faostat/en/\#data/QC (accessed on 16 March 2021).

16. Konieczna, A.; Roman, K.; Roman, M.; Śliwiński, D.; Roman, M. Energy Efficiency of Maize Production Technology: Evidence from Polish Farms. Energies 2021, 14, 170. [CrossRef]

17. Griffiths, B.S.; Philippot, L. Insights into the Resistance and Resilience of the Soil Microbial Community. FEMS Microbiol. Rev. 2013, 37, 112-129. [CrossRef] [PubMed]

18. Barabasz, W.; Pikulick, A. Ochrona Biosfery i Bioróżnorodności. Inż. Ekol. 2012, Nr 30, 7-17.

19. Küçük, Ç.; Tekgül, Y.T. Effects of Cotton Stalk, Maize Stalk and Almond Bark on Some Soil Microbial Activities. Arch. Environ. Prot. 2017, 43, 91-96. [CrossRef]

20. Stark, C.H.; Condron, L.M.; O'Callaghan, M.; Stewart, A.; Di, H.J. Differences in Soil Enzyme Activities, Microbial Community Structure and Short-Term Nitrogen Mineralisation Resulting from Farm Management History and Organic Matter Amendments. Soil Biol. Biochem. 2008, 40, 1352-1363. [CrossRef]

21. García-Orenes, F.; Guerrero, C.; Roldán, A.; Mataix-Solera, J.; Cerdà, A.; Campoy, M.; Zornoza, R.; Bárcenas, G.; Caravaca, F. Soil Microbial Biomass and Activity under Different Agricultural Management Systems in a Semiarid Mediterranean Agroecosystem. Soil Tillage Res. 2010, 109, 110-115. [CrossRef]

22. Cederlund, H.; Wessén, E.; Enwall, K.; Jones, C.M.; Juhanson, J.; Pell, M.; Philippot, L.; Hallin, S. Soil Carbon Quality and Nitrogen Fertilization Structure Bacterial Communities with Predictable Responses of Major Bacterial Phyla. Appl. Soil Ecol. 2014, 84, 62-68. [CrossRef]

23. Barth, G.; Otto, R.; Almeida, R.F.; Cardoso, E.J.B.N.; Cantarella, H.; Vitti, G.C. Conversion of Ammonium to Nitrate and Abundance of Ammonium-Oxidizing-Microorganism in Tropical Soils with Nitrification Inhibitor. Sci. Agric. 2020, 77. [CrossRef] 
24. Kumar, A.; Medhi, K.; Fagodiya, R.K.; Subrahmanyam, G.; Mondal, R.; Raja, P.; Malyan, S.K.; Gupta, D.K.; Gupta, C.K.; Pathak, H. Molecular and Ecological Perspectives of Nitrous Oxide Producing Microbial Communities in Agro-Ecosystems. Rev. Environ. Sci. Biotechnol. 2020, 19, 717-750. [CrossRef]

25. Edesi, L.; Talve, T.; Akk, E.; Võsa, T.; Saue, T.; Loide, V.; Vettik, R.; Plakk, T.; Tamm, K. Effects of Acidified Pig Slurry Application on Soil Chemical and Microbiological Properties under Field Trial Conditions. Soil Tillage Res. 2020, 202, 104650. [CrossRef]

26. FAO. World Reference Base for Soil Resources 2014: International Soil Classification System for Naming Soils and Creating Legends for Soil Maps; FAO: Rome, Italy, 2014; ISBN 978-92-5-108369-7.

27. Pedersen, I.F.; Rubæk, G.H.; Sørensen, P. Cattle Slurry Acidification and Application Method Can Improve Initial Phosphorus Availability for Maize. Plant Soil 2017, 414, 143-158. [CrossRef]

28. Peters, J.; Combs, S.; Hoskins, B.; Jarman, J.; Kovar, J.; Watson, M.; Wolf, A.; Wolf, N. Recommended Methods of Manure Analysis; University of Wisconsin Cooperative Extension Publishing: Madison, WI, USA, 2003.

29. ISO Soil Quality-Determination of Organic and Total Carbon after Dry Combustion (Elementary Analysis) (ISO 10694: 2002); International Organization for Standardization (ISO): Geneva, Switzerland, 2002.

30. Houba, V.J.; van der Lee, J.J.; Novozamsky, I.; Walinga, I. Soil and plant analysis. In Soil Analysis Procedures; Agricultural University, Ed.; Agricultural University: Wageningen, The Netherlands, 1988; pp. 154-158.

31. Schloss, P.D.; Westcott, S.L.; Ryabin, T.; Hall, J.R.; Hartmann, M.; Hollister, E.B.; Lesniewski, R.A.; Oakley, B.B.; Parks, D.H.; Robinson, C.J.; et al. Introducing Mothur: Open-Source, Platform-Independent, Community-Supported Software for Describing and Comparing Microbial Communities. Appl. Environ. Microbiol. 2009, 75, 7537-7541. [CrossRef]

32. Quast, C.; Pruesse, E.; Yilmaz, P.; Gerken, J.; Schweer, T.; Yarza, P.; Peplies, J.; Glöckner, F.O. The SILVA Ribosomal RNA Gene Database Project: Improved Data Processing and Web-Based Tools. Nucleic Acids Res. 2013, 41, D590-D596. [CrossRef]

33. R Core Team. R: A Language and Environment for Statistical Computing; R Foundation for Statistical Computing: Vienna, Austria, 2020.

34. McMurdie, P.J.; Holmes, S. Phyloseq: An R Package for Reproducible Interactive Analysis and Graphics of Microbiome Census Data. PLoS ONE 2013, 8, e61217. [CrossRef]

35. De Mendiburu, F.; Yaseen, M. Agricolae: Statistical Procedures for Agricultural Research; National Engineering University: Lima, Peru, 2020.

36. Fangueiro, D.; Surgy, S.; Fraga, I.; Monteiro, F.G.; Cabral, F.; Coutinho, J. Acidification of Animal Slurry Affects the Nitrogen Dynamics after Soil Application. Geoderma 2016, 281, 30-38. [CrossRef]

37. Das, S.; Jeong, S.T.; Das, S.; Kim, P.J. Composted Cattle Manure Increases Microbial Activity and Soil Fertility More Than Composted Swine Manure in a Submerged Rice Paddy. Front. Microbiol. 2017, 8, 1702. [CrossRef]

38. Hartmann, M.; Frey, B.; Mayer, J.; Mäder, P.; Widmer, F. Distinct Soil Microbial Diversity under Long-Term Organic and Conventional Farming. ISME J. 2015, 9, 1177-1194. [CrossRef] [PubMed]

39. Hartmann, M.; Widmer, F. Community Structure Analyses Are More Sensitive to Differences in Soil Bacterial Communities than Anonymous Diversity Indices. Appl. Environ. Microbiol. 2006, 72, 7804-7812. [CrossRef]

40. Nacke, H.; Thürmer, A.; Wollherr, A.; Will, C.; Hodac, L.; Herold, N.; Schöning, I.; Schrumpf, M.; Daniel, R. Pyrosequencing-Based Assessment of Bacterial Community Structure Along Different Management Types in German Forest and Grassland Soils. PLoS ONE 2011, 6, e17000. [CrossRef] [PubMed]

41. Francioli, D.; Schulz, E.; Lentendu, G.; Wubet, T.; Buscot, F.; Reitz, T. Mineral vs. Organic Amendments: Microbial Community Structure, Activity and Abundance of Agriculturally Relevant Microbes Are Driven by Long-Term Fertilization Strategies. Front. Microbiol. 2016, 7, 1446. [CrossRef] [PubMed]

42. Sun, R.; Zhang, X.-X.; Guo, X.; Wang, D.; Chu, H. Bacterial Diversity in Soils Subjected to Long-Term Chemical Fertilization Can Be More Stably Maintained with the Addition of Livestock Manure than Wheat Straw. Soil Biol. Biochem. 2015, 88, 9-18. [CrossRef]

43. Van der Bom, F.; Nunes, I.; Raymond, N.S.; Hansen, V.; Bonnichsen, L.; Magid, J.; Nybroe, O.; Jensen, L.S. Long-Term Fertilisation Form, Level and Duration Affect the Diversity, Structure and Functioning of Soil Microbial Communities in the Field. Soil Biol. Biochem. 2018, 122, 91-103. [CrossRef]

44. Niewiadomska, A.; Majchrzak, L.; Borowiak, K.; Wolna-Maruwka, A.; Waraczewska, Z.; Budka, A.; Gaj, R. The Influence of Tillage and Cover Cropping on Soil Microbial Parameters and Spring Wheat Physiology. Agronomy 2020, 10, 200. [CrossRef]

45. Eo, J.; Park, K.-C. Long-Term Effects of Imbalanced Fertilization on the Composition and Diversity of Soil Bacterial Community. Agric. Ecosyst. Environ. 2016, 231, 176-182. [CrossRef]

46. Liang, Y.; Wu, L.; Clark, I.M.; Xue, K.; Yang, Y.; Nostrand, J.D.V.; Deng, Y.; He, Z.; McGrath, S.; Storkey, J.; et al. Over 150 Years of Long-Term Fertilization Alters Spatial Scaling of Microbial Biodiversity. mBio 2015, 6. [CrossRef] [PubMed]

47. Ujvári, G.; Borsodi, A.K.; Megyes, M.; Mucsi, M.; Szili-Kovács, T.; Szabó, A.; Szalai, Z.; Jakab, G.; Márialigeti, K. Comparison of Soil Bacterial Communities from Juvenile Maize Plants of a Long-Term Monoculture and a Natural Grassland. Agronomy 2020, 10, 341. [CrossRef]

48. Ho, A.; Di Lonardo, D.P.; Bodelier, P.L.E. Revisiting Life Strategy Concepts in Environmental Microbial Ecology. FEMS Microbiol. Ecol. 2017, 93. [CrossRef]

49. Bligh, E.G.; Dyer, W.J. A Rapid Method of Total Lipid Extraction and Purification. Can. J. Biochem. Physiol. 1959, $37,911-917$. [CrossRef] [PubMed] 
50. Geisseler, D.; Scow, K.M. Long-Term Effects of Mineral Fertilizers on Soil Microorganisms-A Review. Soil Biol. Biochem. 2014, 75, 54-63. [CrossRef]

51. Lazcano, C.; Gómez-Brandón, M.; Revilla, P.; Domínguez, J. Short-Term Effects of Organic and Inorganic Fertilizers on Soil Microbial Community Structure and Function. Biol. Fertil. Soils 2013, 49, 723-733. [CrossRef]

52. Li, G.; Wu, C. Effects of Short-Term Set-Aside Management Practices on Soil Microorganism and Enzyme Activity in China. Int. J. Environ. Res. Public Health 2017, 14, 913. [CrossRef] [PubMed]

53. Gomiero, T.; Pimentel, D.; Paoletti, M.G. Environmental Impact of Different Agricultural Management Practices: Conventional vs. Organic Agriculture. Crit. Rev. Plant Sci. 2011, 30, 95-124. [CrossRef]

54. Hole, D.G.; Perkins, A.J.; Wilson, J.D.; Alexander, I.H.; Grice, P.V.; Evans, A.D. Does Organic Farming Benefit Biodiversity? Biol. Conserv. 2005, 122, 113-130. [CrossRef]

55. Stark, C.; Condron, L.M.; Stewart, A.; Di, H.J.; O'Callaghan, M. Influence of Organic and Mineral Amendments on Microbial Soil Properties and Processes. Appl. Soil Ecol. 2007, 35, 79-93. [CrossRef]

56. Roberts, B.A.; Fritschi, F.B.; Horwath, W.R.; Scow, K.M.; Rains, W.D.; Travis, R.L. Comparisons of Soil Microbial Communities Influenced by Soil Texture, Nitrogen Fertility, and Rotations. Soil Sci. 2011, 176, 487-494. [CrossRef] 